\title{
The Situation of Cystic Echinococcoses in Kars State Hospital for The Last Five Years
}

\author{
Kars İli Devlet Hastanesinde Kistik Ekinokokkozisin Son Beş Yıldaki Durumu
}

\author{
Neriman Mor ${ }^{1}$, Tülay Diken Allahverdi², Turgut Anuk ${ }^{2}$ \\ 'Kafkas Üniversitesi Kars Sağlık Yüksekokulu, Kars, Turkey \\ ${ }^{2}$ Kafkas Üniversitesi Tıp Fakültesi Genel Cerrahi Anabilim Dalı, Kars, Turkey
}

\begin{abstract}
Objective: This study was conducted to contribute to the information regarding the spread of cystic echinococcosis (CE) in our country and to reveal its importance in our region by determining the spread of CE in people.

Methods: CE cases, which were detected by retrospectively reviewing the records at Kars State Hospital in Kars between 2009 and 2013 , were evaluated in terms of age group, gender, and organ involvement. For features, descriptive statistics were stated in numbers and percentages.

Results: According to the obtained results, in total, 168 CE cases were specified. While female patients constitute 101 cases (60.1\%), male patients constitute the remaining (39.9\%). Their distribution was specified between the ages of 3 and 79 years, and it was ascertained that the cases were mostly between the age groups of 16 and 30 years at the rate of $26.8 \%$. The second most frequent age group was between 31 and 45 years at the rate of $25.6 \%$. CE was mostly seen in the lung (49.4\%) and liver (44.6\%). Additionally, 10 patients with CE in both the lung and liver were ascertained.

Conclusion: It is seen that CE is an important public health problem in Kars. Extensive protection and control programs should be implemented against this disease. (Turkiye Parazitol Derg 2015; 39: 108-11)
\end{abstract}

Keywords: Cystic echinococcosis, retrospective research, Kars, Turkey

Received: 16.07.2014

Accepted: 18.11.2014

\section{ÖZET}

Amaç: Bu çalışma, bölgemiz insanında kistik ekinokokkozisin (KE) yayılışı hakkında bir saptama yaparak hastalığın ülkemizdeki yayılışına ait bilgilere katkıda bulunmak ve bölgemiz için önemini ortaya koymak amacıyla yapılmıştır.

Yöntemler: Kars Il'inde 2009-2013 yılları arasında Kars Devlet Hastanesi kayıtları retrospektif olarak gözden geçirilerek saptanan KE olguları yaş, cinsiyet ve organ tutulumu yönünden değerlendirilmiştir. Özellikler için tanımlayıcı istatistikler sayı ve yüzde olarak ifade edilmiştir.

Bulgular: Elde edilen sonuçlara göre toplam $168 \mathrm{KE}$ olgusu belirlenmiştir. Olguların 101'ini $(\% 60,1)$ kadın, 67'sini $(\% 39,9)$ erkek hastalar oluşturmuştur. Yaşa göre dağılımları 3 ve 79 yaş arasında belirlenmiş olup, olguların en sık \%26,8 oranıyla 16-30 yaş, ikinci sıklıkta \%25,6 oranıyla 31-45 yaş arasında olduğu tespit edilmiştir. KE en sık yerleştiği organlar akciğer $(\% 49,4)$ ve karaciğer $(\% 44,6)$ idi. Bunları karaciğer + akciğer olarak 10 hasta $(\% 6,0)$ izledi.

This study was presented as a poster at the $7^{\text {th }}$ National Hydatidology Congress, 4-7 September 2014, Ordu, Turkey. Bu çalışma 7. Ulusal Hidatidoloji Kongresi'nde poster olarak sunulmuştur, 4-7 Eylül 2014, Ordu, Türkiye.

Address for Correspondence / Yazışma Adresi: Dr. Neriman Mor, Kafkas Üniversitesi Kars Sağlık Yüksekokulu, Kars, Turkey. Phone: +90 4742251265 E-mail: nery.man@hotmail.com DOI: $10.5152 /$ tpd.2015.3728

CTelif hakkı 2015 Türkiye Parazitoloji Derneği - Makale metnine www.tparazitolderg.org web sayfasından ulaşılabilir. CCopyright 2015 Turkish Society for Parasitology - Available online at www.tparazitolderg.org 
Sonuç: Kistik ekinokokkozisin Kars ilinde önemli bir halk sağlığı problemi olduğu görülmüştür. Bu hastalığa karşı geniş çaplı korunma ve kontrol programları uygulanması gerekmektedir. (Turkiye Parazitol Derg 2015; 39: 108-11)

Anahtar Sözcükler: Kistik ekinokokkozis, retrospektif inceleme, Kars, Türkiye

Geliş Tarihi: 16.07.2014

Kabul Tarihi: 18.11.2014

\section{INTRODUCTION}

Cystic echinococcosis (CE) is a widespread helminth zoonotic disease in our country and also all over the world. The larvae of Echinococcus granulosus cause this disease, and its adult form locates in the small intestine of dogs and other canines, which are the definitive host. However, its larval form locates in the internal organs of animals such as sheep, goats, cattle, and pigs and rarely humans, which are intermediate hosts. When carnivores eat infected an intermediate host animals' raw organs with a parasitic cyst, the larvae become adult parasites in their small intestine, and their eggs are excreted in the feces. Excreted parasite eggs give rise to CE by being taken via digestion and rarely respiration by the intermediate hosts. An oncosphere, which projects from eggs hatching in the gastrointestinal tract in an intermediate host, goes into the portal circulation by penetrating the intestinal wall. Embryos locating in the liver primarily constitute liquid-filled cysts. It passes into the systemic circulation by exceeding liver sinusoids rarely and locates in all the organs. It is most frequently located in the liver and lung. It can form cysts in other organs, such as the heart, kidney, spleen, brain, soft tissue, and rarely in the bone (1-5). It is endemic in some regions, such as South America, East Africa, Central Asia, China, Australia, New Zealand, and Mediterranean countries where sheep and cattle breeding are most frequent (6-8). As for Turkey, factors such as subsistence based on agriculture and stockbreeding, low socio-economic structure, climatic conditions, and uncontrolled and illegal slaughtering have raised the rate of CE (9). East Anatolia, South-east Anatolia, and Central Anatolia are the regions where the disease is most common; its prevalence varies from region to region $(6,9)$. It is rarely seen in the western regions where people who migrate from the eastern regions live intensively (4).

The data about the prevalence of CE for people in our country are generally the ones obtained from hospital records with the help of seroepidemiologic studies (9-18). There has been only one study conducted on humans in Karson on the prevalence of CE, and its serological prevalence was reported to be $34.6 \%$ (19). Because CE cases have not been examined to date using the hospital records of CE cases detected between 2009 and 2013 in Kars as a standard, this study was conducted to obtain information about the disease's current condition by comparing the previous data in other regions and to determine to what extent it is a threat risk for people in terms of public health.

\section{METHODS}

For this study, 168 CE patients in whom surgical intervention was performed between 01.01.2009 and 12.31.2013 were examined by analyzing operating room records of Kars State Hospital. The records belonging to patients were retrospectively reviewed. Using the information in the patients' reports as a standard, they were evaluated in terms of age group, gender, clinics where they were treated, and organs with parasites. For features, descriptive statistics were expressed as numbers and percentages.

\section{RESULTS}

The ages of 168 CE patients in whom surgical intervention was performed during the five-year period varied from 3 to 79 years. In total, 101 patients were females, and the remaining were males. The distribution of the patients in terms of gender, age group, clinics where they were treated, and the region where cyst located is presented in Table 1.

\section{DISCUSSION}

CE is seen worldwide; it is mostly in regions where stockbreeding is common. It frequently locates in the liver and lung, causes considerable health problems and economic losses, and is caused by $E$. granulosus $(1,3)$. It is stated that the disease is seen more often in females in the studies conducted throughout Turkey. Kılınç et al. (5) stated that $61.2 \%$ of the patients were females and that $38.2 \%$ of the patients were males in Diyarbakır. In Kayseri, the records of different hospitals and the Local Health Authority were examined in terms of CE between 1999 and 2004. According to the results, of a total of 699 patients, 330 (47.2\%) were males and 369 (52.8\%) were females (12). Delibaş et al. (20) stated that 50 (63\%) of 80 were females and 30 (37\%) were males who were definitively diagnosed with CE after being operated for CE. In the study conducted by Hakverdi et al. (13), $69.23 \%$ of 26 patients were female and $30.76 \%$ were males. Kaplan et al. (14), stated that $54.8 \%$ of the patients were female and $45.2 \%$ were male in their studies. In our study, 101 (60.1\%) of the 168 patients were females and 67 (39.9\%) were males. Although there are publications reporting that the disease is more common in males $(21,22)$, there are some studies reporting that the parasite causes the disease in both genders equally $(11,23)$. In our study, it was identified that the patients were mainly people coming from rural areas. It can be explained that males are occupied with agriculture and digging, while females take up animal husbandry, cooking, and cleaning. In the studies about CE in our country, it is stated that the disease can be seen across all ages and that the infection caught during childhood reveals a symptom between 20 and 50 years frequently (10). Delibaş et al. (20) stated in their studies that $46 \%$ of patients were between the ages of 40 and 60 years. In our cases that were reviewed, the youngest patient was 3 years and the oldest was 79 . The patients were most frequently between the age group of 16 and 30 years with the rate of $26.8 \%$. The second most frequent age group was between 31 and 45 years with the rate of $25.6 \%$, and the third most frequent was between 46 and 60 years with the rate of $20.2 \%$. The distribution of these cases in terms of age is parallels with other studies, and it is highly seen during the middle age. In the studies conducted in Turkey, it was reported that CE is seen in the liver most frequently and then in the lung and rarely in other organs $(1,10,20)$. Similar to our study, CE was seen most frequently in the lung (49.4\%), followed by the liver (44.6\%), and lung involvement was more frequent than other studies. In CE cases located in the liver, only Type I, II, and III cases are operated, whereas liquid non-inclusive Gharbi Type IV and calcified Type V 
Table 1. Distribution of patients in terms of age group, gender, clinics where they were treated, and the region where cyst located

\begin{tabular}{|c|c|c|c|c|c|c|c|c|c|c|c|c|}
\hline \multirow[b]{2}{*}{ Distribution of patients } & \multicolumn{2}{|c|}{2009} & \multicolumn{2}{|c|}{2010} & \multicolumn{2}{|c|}{2011} & \multicolumn{2}{|c|}{2012} & \multicolumn{2}{|c|}{2013} & \multicolumn{2}{|c|}{ Total } \\
\hline & $\mathrm{n}$ & $\%$ & $\mathbf{n}$ & $\%$ & $\mathrm{n}$ & $\%$ & $\mathrm{n}$ & $\%$ & $\mathbf{n}$ & $\%$ & $\mathbf{n}$ & $\%$ \\
\hline \multicolumn{13}{|l|}{ Gender } \\
\hline Female & 30 & 29.7 & 10 & 9.9 & 28 & 27.7 & 28 & 27.7 & 5 & 5.0 & 101 & 60.1 \\
\hline Male & 15 & 22.4 & 7 & 10.5 & 21 & 31.3 & 21 & 31.3 & 3 & 4.5 & 67 & 39.9 \\
\hline \multicolumn{13}{|l|}{ Age Group } \\
\hline $0-15$ & 1 & 4.5 & - & - & 10 & 45.5 & 10 & 45.5 & 1 & 4.5 & 22 & 13.1 \\
\hline $16-30$ & 8 & 17.8 & 6 & 13.3 & 16 & 35.6 & 13 & 28.9 & 2 & 4.4 & 45 & 26.8 \\
\hline $31-45$ & 15 & 34.9 & 7 & 16.3 & 5 & 11.6 & 13 & 30.2 & 3 & 7.0 & 43 & 25.6 \\
\hline $46-60$ & 14 & 41.1 & 3 & 8.8 & 11 & 32.4 & 4 & 11.8 & 2 & 5.9 & 34 & 20.2 \\
\hline $61-75$ & 4 & 20.0 & 1 & 5.0 & 7 & 35.0 & 8 & 40.0 & - & - & 20 & 11.9 \\
\hline 76 ve üstü & 3 & 75.0 & - & - & - & - & 1 & 25.0 & - & & 4 & 2.4 \\
\hline \multicolumn{13}{|l|}{ Clinic } \\
\hline General surgery & 10 & 14.5 & 14 & 20.3 & 12 & 17.4 & 27 & 39.1 & 6 & 8.7 & 69 & 41.1 \\
\hline Thoracic surgery & 35 & 45.4 & 3 & 3.9 & 24 & 31.2 & 14 & 18.2 & 1 & 1.3 & 77 & 45.8 \\
\hline Pediatric surgery & - & - & - & - & 13 & 59.1 & 8 & 36.4 & 1 & 4.5 & 22 & 13.1 \\
\hline \multicolumn{13}{|l|}{ Region with Cyst } \\
\hline Lung & 32 & 38.6 & 3 & 3.6 & 28 & 33.7 & 19 & 22.9 & 1 & 1.2 & 83 & 49.4 \\
\hline Liver & 13 & 17.3 & 14 & 18.7 & 14 & 18.7 & 29 & 38.7 & 5 & 6.6 & 75 & 44.6 \\
\hline Lung+Liver & - & & - & & 7 & 70.0 & 1 & 10.0 & 2 & 20.0 & 10 & 6.0 \\
\hline Total & 45 & 26.8 & 17 & 10.1 & 49 & 29.2 & 49 & 29.2 & 8 & 4.7 & 168 & 100.0 \\
\hline
\end{tabular}

cysts are not operated, but patient follow-up is done. Additionally, because of the high patient density in general surgery clinics, canalizing the patients to other clinics has suggested the possibility of showing this result on reviewing the records. It is stated in literature that the involvement of more than one organ was monitored in $20-30 \%$ of the cases $(24,25)$. While Delibaş et al. (20) stated that shared involvement of lung and liver was $16.2 \%$, Özekinci et al. (25) and Kılınç et al. (5) stated this rate to be $8.11 \%$ and $7.6 \%$, respectively, in their studies. For our study, the shared involvement of lung and liver was present in 10 cases (6.0\%).

When case distribution is looked by years, only 8 (4.7\%) cases were encountered in 2013. It was determined that there was a serious decrease compared with other years. The patients' first reason for preferring Medical Faculty Research Hospital in Kars is that better operating room conditions are present there and that most of the surgical operations are conducted in this hospital. Additionally, percutaneous drainage with USG in treatment modalities is preferred in recent years. Percutaneous drainage, which is a more comfortable and economical method and which requires a short hospital stay, is an alternative to surgery. This is the reason why patients could be directed to advanced treatment centers.

CE has a broad distribution and high contamination feature in our country and worldwide. In Kars, where the study was conducted, the prevalence of CE was rather high. Kurtpınar et al. (26) identified the prevalence of the infection of ruminant animals in animals slaughtered in Kars slaughterhouse between 1950 and 1955 and indicated that the prevalence of CE was 50\% in cattle and that the prevalence was insignificant in sheep and goats without expressing a rate. Umur et al. (27) stated that the infection rate of animals slaughtered in Kars municipality slaughterhouse in 1992 was $24.65 \%$ in cattle, $48.35 \%$ in sheep, and $25.11 \%$ in goats. Gıcık et al. (28) ascertained infection at the rate of $31.25 \%$ in cattle and $63.85 \%$ in sheep slaughtered in the Kars slaughterhouse between 2001 and 2003. Later, Demir et al. (29) found CE in 203 (5.3\%) of 3.846 cattle slaughtered in the Kars municipality slaughterhouse between January and December 2010. In a study conducted on street dogs in this region between 1995 and 1997, adult E. granulosus was encountered at the rate of $40.5 \%$ with sampling method on dogs for which echinococcosis types are seen intensively as a result of coprology and postmortem on dogs. (30). However, there is only one study conducted on people in Kars; seropositivity was ascertained in the serum of 511 people living in the center of Kars and its villages at the rate of $34.6 \%$ using IHA and IFA by Karaman et al. (19)

\section{CONCLUSION}

As a result, it can be said that the prevalence of CE in domestic animals, which are appropriate for slaughtering, and people in Kars is risky in terms of the health of animals and people in the region and causes considerable economic losses. Locals should be informed of CE, which is one of the important zoonosis in the world, in terms of contamination manners and prophylaxis. Required precautions should be taken for stray dogs, in particular; uncontrolled and illegal slaughtering should be prevented, and organs with cysts should be annihilated under suitable conditions. Such kinds of protection and control methods may form an effective eradication program and help lower the prevalence of the disease. 
Ethics Committee Approval: Ethics Committee Approval was not received due to the retrospective nature of the study.

Informed Consent: Informed consent was not received due to the retrospective nature of the study.

Peer-review: Externally peer-reviewed.

Author Contributions: Concept - N.M.; Design - N.M., T.D.A.; Supervision - T.A.; Data Collection and/or Processing - N.M., T.D.A., T.A.; Analysis and/or Interpretation - N.M., T.D.A.; Literature Review - N.M., T.D.A., T.A.; Writing - N.M.; Critical Review - T.D.A., T.A.

Acknowledgement: We thank the staff members helping to collect data used in this study.

Conflict of Interest: No conflict of interest was declared by the authors.

Financial Disclosure: The authors declared that this study has received no financial support.

Etik Komite Onayı: Çalışmamızın retrospektif tasarımından dolayı etik kurul onayı alınmamıştır.

Hasta Onamı: Çalışmamızın retrospektif tasarımından dolayı hasta onamı alınmamıştır.

Hakem Değerlendirmesi: Dış Bağımsız.

Yazar Katkıları: Fikir - N.M.; Tasarım - N.M., T.D.A.; Denetleme - T.A.; Veri Toplanması ve/veya işlemesi - N.M., T.D.A., T.A.; Analiz ve/veya Yorum N.M., T.D.A.; Literatür taraması - N.M., T.D.A., T.A.; Yazıyı Yazan - N.M.; Eleştirel İnceleme - T.D.A., T.A.

Teşekkür: Bu çalışmada kullanılan bilgilerin toplanmasında bize yardımcı olan çalışanlara teşekkür ederiz.

Çıkar Çatışması: Yazarlar çıkar çatışması bildirmemişlerdir.

Finansal Destek: Yazarlar bu çalışma için finansal destek almadıklarını beyan etmişlerdir.

\section{REFERENCES}

1. Özbilgin A, Kilimcioğlu AA. Kistik echinococcosis. Özcel MA editör. Özcel'in Tıbbi Parazit Hastalıkları. Birinci baskı. İmir: Türkiye Parazitoloji Derneği Yayını 22; 2007. p. 541-65.

2. Altintaş N. Past to present: echinococcosis in Turkey. Acta Tropica 2003; 85: 105-12. [CrossRef]

3. Altıntaş N, Tınar R, Çoker A. Echinococcosis. Hidatoloji Derneği Yayın 1; 2004: 129-238.

4. Canda MŞ, Güray M, Canda T, Astarcıoğlu H. The pathology of echinococcosis and the current echinococcosis problem in western Turkey (A report of pathologic features in 80 cases). Turk J Med Sci 2003; 33: 369-74.

5. Kılınç N, Uzunlar AK, Özaydın M. Seyrek yerleşimli ekinokokkozis olguları (45 olgu). Türkiye Ekopatol Derg 2003; 9: 25-30.

6. Unat EK, Yücel A, Atlaş K, Samastı M. Unat'ın Tıp Parazitolojisi (5. baskı). Cer Tıp Fak Vakfı Yayın 15; 1995: 19-49.

7. Athanassiadi K, Kalavrouziotis G, Loutsidis A, Bellenis I, Exarchos N. Surgical teratment of echinococcozis by atransthoracic approach: a review of 85 cases. European Journal of Cardio-thoracic Surgery 1998; 14: 134-40. [CrossRef]

8. Yazar S, Taylan Özkan A, Hökelek M, Polat E, Yılmaz H, Özbilge H, ve ark. Türkiye'de 2001-2005 yılları arasında kistik ekinokokkozis. Türkiye Parazitol Derg, 2008; 32: 208-20.

9. Altıntaş N, Yazar S, Yolasığmaz A, Akısü Ç, Şakru N, Karacasu F, et al. A serum epidemiological study of cystic echinococcosis in Izmir and is surrounding area, Turkey. Helminthologia 1999; 36: 19-23.
10. Ertuğ S, Sarı C, Gürel M, Boylu Ş, Çanakkalelioğlu L, Şahin B. Aydın ve çevresinde 1996-2000 yılları arasında cerhi olarak saptanan kist hidatik olguları. Türkiye Parazitol Derg 2002; 26: 254-6.

11. Gündoğdu C, Arslan R, Arslan MÖ, Gıık Y. Erzurum ve çevresinde insanlarda kistik ve alveoler ekinokokkozis olgularının değerlendirilmesi. Türkiye Parazitol Derg 2005; 29: 163-6.

12. Yazar S. Kayseri'de kistik ekinokokkozisin son altı yıldaki durumu. Türkiye Parazitol Derg 2005; 29: 241-3.

13. Hakverdi S, Çulha G, Canda MŞ, Yaldız M, Altıntaş S. Hatay ili'nde kistik ekinokokkozis sorunu. Türkiye Parazitol Derg 2008; 32: 340-2.

14. Kaplan M, Aygen E, Özyurtkan MO, Bakal Ü. 2005-2007 Yılları arasında fırat üniversitesi hastanesindeki kistik ekinokokkoz olguları. F Ü Sağ BilTıp Derg 2010; 24: 109-13.

15. Karadağ A, Yanık K, Ünal N, Odabaşı H, Hökelek M. Kistik ekinokokkozis şüphesi ile 2005-2011 yılları arasında ondokuz mayıs üniversitesi tıp fakültesi parazitoloji laboratuvarına gönderilen örneklerin değerlendirilmesi. Turkiye Parazitol Derg 2013; 37: 28-31.

16. Aksu M, Kırcalı Sevimli F, Ibiloğlu I, Bozdoğan Arpacı R. Mersin ili'nde kistik ekinokokkozis (119 olgu). Turkiye Parazitol Derg 2013; 37: 252-6. [CrossRef]

17. Karadağ A, Yanık K, Ünal N, Odabaşı H, Hökelek M. Kistik ekinokokkozis şüphesi ile 2005-2011 yılları arasında ondokuz mayıs üniversitesi tıp fakültesi parazitoloji laboratuvarına gönderilen örneklerin değerlendirilmesi. Turkiye Parazitol Derg 2013; 37: 28-31.

18. Yılmaz, H, Cengiz ZT, Çiçek $M$. Yüzüncü yıl üniversitesi araştırma ve uygulama hastanesi parazitoloji laboratuarında 1998-2005 yılları arasında saptanan uniloküler kist hidatik olguları. Türkiye Parazitol Derg 2013; 37: 249-51. [CrossRef]

19. Karaman Ü, Miman Ö, Kara M, Gııık Y, Aycan ÖM, Atambay M. Kars bölgesinde hidatik kist prevalansı. Turkiye Parazitol Derg 2005; 29: 238-40.

20. Delibaş BS, Özkoç S, Şahin S, Aksoy Ü, Akısü Ç. Dokuz eylül üniversitesi tıp fakültesi parazitoloji anabilim dalı seroloji laboratuvarı'na kistik ekinokokkozis şüphesiyle başvuran hastaların değerlendirilmesi Türkiye Parazitol Derg 2006; 30: 279-81.

21. Koltaş is, Koç Z, Demirci M, Aktaş H, Parsak CK, Özerdem D. Akdeniz bölgesinde cystic echinococcosis. 3. Ulusal Hidatidoloji Kongresi 6-9 Eylül 2006, Samsun. Kongre Özet Kitabı; 24.

22. Miman Ö, Atambay M, Aydın NE, Daldal N. Kistik ekinokokkozis nedeniyle opere edilmiş 91 olguda klinik, morfolojik ve serolojik irdelemeler. Türkiye Parazitol Derg 2010; 34: 179-83.

23. Atambay M, Türkmen E, Karaman Ü, Söğütlü G, Aydın EN, Daldal N. Uniloküler kistik ekinokokkozis olgularında yapısal değişiklikler. Türkiye Ekopatol Derg 2005; 11: 71-2.

24. Arslan A, Uzunlar AK, Hakverdi S, Büyükbayram H, Özaydın M. Karaciğer ekinokokkozisi T Klin J Gastroenterohpatol 1996; 7: 57-9.

25. Özekinci S, Bakır Ş, Mızrak B. 2002-2007 yılları arasında Diyarbakır'da histopatolojik tanı alan kistik ekinokokkozis olgularının değerlendirilmesi. Türkiye Parazitol Derg 2009; 33: 232-5.

26. Kurtpınar H. Erzurum, Kars ve Ağrı vilayetleri sığır, koyun ve keçilerinin yaz aylarına mahsus parazitleri ve bunların doğurdukları hastalıklar. Türk Vet Hek Dern Derg 1957; 27: 3320-5.

27. Umur Ş, Aslantaş Ö. Kars belediye mezbahası'nda kesilen ruminantlarda hidatidozun yayılışı ve ekonomik önemi. Türkiye Parazitol Derg 1993; 17: 27-34.

28. Gıcık Y, Arslan MÖ, Kara M, Köse M. Kars ilinde kesilen sığır ve koyunlarda kistik ekinokokkozis'in yaygınlığı. Turkiye Parazitol Derg 2004; 28: 136-9.

29. Demir P, Mor N. Kars belediye mezbahasında kesilen sığırlarda kistik echinococcosis'in yaygınlığı, mevsimsel dağılımı ve ekonomik önemi. Turkiye Parazitol Derg 2011; 35: 185-8. [CrossRef]

30. Umur Ş, Arslan MÖ. Kars yöresi sokak köpeklerinde görülen helmint türlerinin yayılışı. Türkiye Parazitol Derg 1998; 2: 188-93. 